\title{
Natural Dye-Sensitized Solar Cells Based on Highly Ordered $\mathrm{TiO}_{2}$ Nanotube Arrays
}

\author{
Na Li, Nengqian Pan, Danhong Li, and Shiwei Lin \\ Key Laboratory of Ministry of Education for Advanced Materials in Tropical Island Resources, School of Materials and \\ Chemical Engineering, Hainan University, Haikou 570228, China
}

Correspondence should be addressed to Shiwei Lin; linsw@hainu.edu.cn

Received 27 January 2013; Accepted 21 April 2013

Academic Editor: Theodoros Dimopoulos

Copyright (C) $2013 \mathrm{Na} \mathrm{Li}$ et al. This is an open access article distributed under the Creative Commons Attribution License, which permits unrestricted use, distribution, and reproduction in any medium, provided the original work is properly cited.

The dye-sensitized solar cells (DSSCs) have been fabricated using highly ordered $\mathrm{TiO}_{2}$ nanotube arrays as photoelectrode and natural dyes as photosensitizers. The natural dyes were extracted from the abundant plants in the tropical region, such as Tradescantia zebrina, kapok, and pitaya. The dyes could chemically couple with $\mathrm{TiO}_{2}$ nanotubes and effectively convert visible light into electricity in DSSCs. A power conversion efficiency could be achieved up to $0.3 \%$ in the solar cell sensitized by the extracts from kapok with a short-circuit current of $0.86 \mathrm{~mA} / \mathrm{cm}^{2}$. Furthermore, the influences of the crystal structure of $\mathrm{TiO}_{2}$ nanotube arrays on the performance of the natural DSSCs were discussed.

\section{Introduction}

Photosensitized wide-band gap metal-oxide semiconductors are used to convert visible light into electricity $[1,2]$. In most dye-sensitized solar cells (DSSCs), nanocrystalline $\mathrm{TiO}_{2}$ films are used as photo-electrode due to their impressive properties when compared to other metal-oxide semiconductors. Most recently, different $\mathrm{TiO}_{2}$ nanostructures (nanotubes, nanorods, nanowires, nanoparticles, etc.) are explored as dye carriers [3-8]. Compared to other nanostructures, $\mathrm{TiO}_{2}$ nanotubes (TNTs) enhance much visible-light scattering and absorption due to their high length-to-diameter ratio and large surface area and facilitate electron transportation to the electrodes due to their unique geometry [9-12].

One of the key elements in DSSCs is photosensitizer. The most successful photo-induced electron transfer sensitizers employed so far in DSSCs are ruthenium (II) polypyridyl complexes. The ruthenium complexes in DSSCs have exhibited power conversion efficiencies up to $12 \%$ [13]. Due to the high cost of ruthenium complexes and the scarce availability of those noble metals, looking for cheaper, simpler, and safer sensitizers becomes a scientific challenging problem [14]. Natural pigments, including chlorophyll, anthocyanin, nasunin, and carotenoids, can fulfill those requirements, and sensitization of $\mathrm{TiO}_{2}$ by natural pigments has been reported
[15-19]. Experimentally, natural dye-sensitized $\mathrm{TiO}_{2}$ solar cells have reached an efficiency of 7.1\% [17].

Natural pigments extracted from leaves, flowers, and fruits of plants have advantages over rare metal complexes and other organic dyes. The natural dyes are readily available, easy to extract, of less cost, and environmentally friendly. In this work, we have made an attempt to collect red pigments from Tradescantia zebrina, kapok, and pitaya, as these plants are abundant in Hainan, the tropical island of China. The natural dyes were used to sensitize the highly ordered $\mathrm{TiO}_{2}$ nanotube arrays fabricated by chemical anodization technique. Then DSSCs were assembled, and the photoelectrical properties were investigated.

\section{Experimental}

2.1. Preparation of Natural Dye-Sensitized $\mathrm{TiO}_{2}$ Solar Cells. Ti foils ( $0.5 \mathrm{~mm}$ thickness, $99.4 \%$ purity) were sequentially cleaned in acetone, ethanol, and deionized (DI) water. Anodization was then performed in a two-electrode configuration with titanium foil as the working electrode and a stainless steel foil as the counter electrode $[11,12,20]$. A direct current power supply was used as the voltage source to drive the anodization. The electrolyte consisted of $0.3 \mathrm{wt} \%$ $\mathrm{NH}_{4} \mathrm{~F}$ and $2 \mathrm{vol} \% \mathrm{H}_{2} \mathrm{O}$ in ethylene glycol. The anodization 


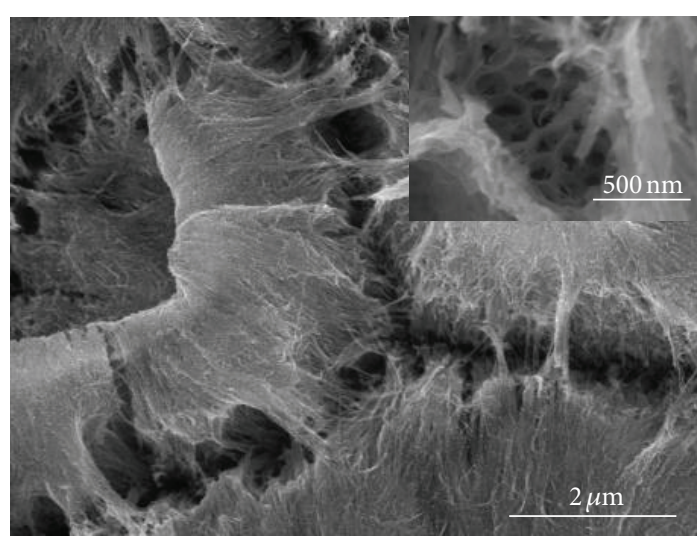

(a)

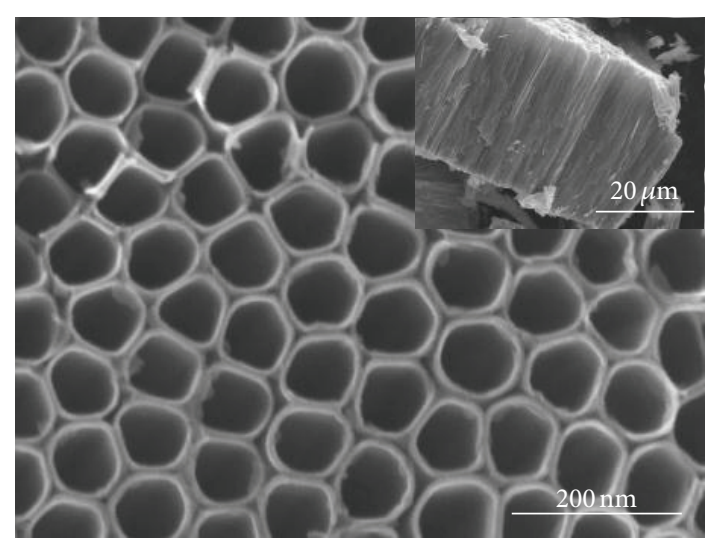

(b)

FIgURE 1: Top view SEM images of $\mathrm{TiO}_{2}$ nanotube arrays (a) before and (b) after the ultrasonic treatment. The inset in (a) is the image with high magnification, while the inset in (b) shows the cross-sectional view of the nanotube arrays after ultrasonic treatment.

was conducted at $60 \mathrm{~V}$ for $2 \mathrm{~h}$ at room temperature. After anodization, the samples were annealed at $500^{\circ} \mathrm{C}$ or $600^{\circ} \mathrm{C}$ for $2 \mathrm{~h}$ in air with the temperature rising rate of $2^{\circ} \mathrm{C} / \mathrm{min}$.

All the fresh fruits and flowers were harvested in Hainan, the tropical island in China. The extracts of Tradescantia zebrina, kapok, and pitaya were obtained according to the similar steps as followed. The fresh fruits or flowers well cleaned (200 g) were crushed and soaked in 95\% ethanol $(50 \mathrm{~mL})$ and then kept for $24 \mathrm{~h}$ in dark at room temperature. The residual parts were filtered. The clear solutions were centrifuged and diluted $\mathrm{HCl}$ was added to adjust the $\mathrm{pH}$ value. The solution with the extracts became red in color, and the natural dyes were ready to use as sensitizers in DSSCs.

$\mathrm{TiO}_{2}$ nanotube array electrodes were immersed at room temperature for $12 \mathrm{~h}$ in dark in the solution with the extracts, respectively. To evaluate the photovoltaic performance, $\mathrm{TiO}_{2}$ nanotube array electrode and $\mathrm{Pt}$ counter electrode were assembled to form a DSSC. The electrolyte was injected into the space between the two electrodes. The redox electrolyte with $\left[\mathrm{I}^{-3}\right] /\left[\mathrm{I}^{-}\right]=1: 9$ was prepared by dissolving $0.5 \mathrm{M} \mathrm{LiI}$ and $0.05 \mathrm{M} \mathrm{I}_{2}$ in acetonitrile solution.

2.2. Characterization of Natural Dye-Sensitized $\mathrm{TiO}_{2}$ Solar Cells. The morphology and crystal structure of $\mathrm{TiO}_{2}$ nanotube-array electrode were characterized by field-emission scanning electronic microscopy (FESEM, Hitachi S4800, Japan) and X-ray diffraction technique (XRD, Bruker D8, Germany), respectively. The absorption spectrum of three kinds of natural extracts in solution and adsorbed onto $\mathrm{TiO}_{2}$ photoanode were measured by UV-visible absorption spectra measurements (Persee, TU-1901). Photocurrentphotovoltage characteristics of the natural dye-sensitized solar cells were measured by the electrochemical workstation (Zahner 6.0, Germany) with a xenon source with intensity of $50 \mathrm{~mW} / \mathrm{cm}^{2}$. The effective cell area was $1.0 \mathrm{~cm}^{2}$.

\section{Results and Discussion}

3.1. Characteristics of $\mathrm{TiO}_{2}$ Nanotube-Array Electrode. Figure 1(a) shows the SEM image of the sample without ultrasonic treatment. The surface is covered with a layer of grassy residual and the nanotubes underneath are visible as shown in the inset of Figure 1(a). The grassy layer could block the infiltration of the dye and the redox electrolyte into the nanotubes. Thus it must be removed before the nanotubes are assembled into the DSSC [9]. Ultrasonic treatment can remove the grassy layer and expose the underneath nanotubes, as shown in Figure 1(b). The nanotubes are well defined. As the nanotubular structure provides a high specific surface area, the nanotubes can absorb more dyes on the electrode surface as compared with the planar film.

Before being assembled into DSSCs, the samples were annealed for crystallization of the $\mathrm{TiO}_{2}$, since a large number of localized states in the amorphous structure without annealing can act as traps and recombination centers [21]. Figure 2 shows the XRD patterns of $\mathrm{TiO}_{2}$ nanotubes annealed at different temperatures. It is evidenced that $\mathrm{TiO}_{2}$ transforms from amorphous phases to crystalline anatase phases and rutile phases after the annealing at $500^{\circ} \mathrm{C}$. When the temperature increased to $600^{\circ} \mathrm{C}$, the peaks relate to rutile phase increase.

\subsection{Spectroscopic Characterization of Natural Photosensitiz-} ers. Figure 3(a) presents the absorption spectra of the red pigments in acid solutions, which were extracted from Tradescantia zebrina, kapok, and pitaya, respectively. The absorption peaks of the extracts from Tradescantia zebrina in visible-light region have maximums at $540 \mathrm{~nm}$ and $584 \mathrm{~nm}$, which show typical absorption of anthocyanin [22]. For the extracts from kapok in solution, the maximum of the absorption intensity in visible-light region is located at $406 \mathrm{~nm}$ and $508 \mathrm{~nm}$, which correspond to the absorption of carotenoid $[18,23]$ and anthocyanin, respectively. And the absorption peak obtained for extracts from pitaya in visible-light region is at $400 \mathrm{~nm}$. As shown in Figure 3(a), these red pigments in solution have maximum absorption peaks at $350 \mathrm{~nm}$ and $380 \mathrm{~nm}$ in ultraviolet region. The same locations of the absorption peaks mean that they contain similar compounds. 


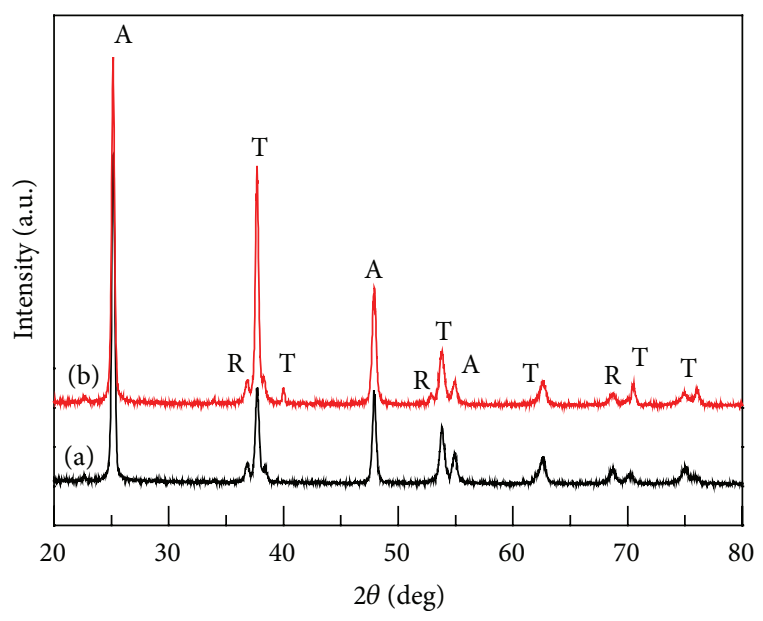

FIGURE 2: XRD patterns of (a) the $\mathrm{TiO}_{2}$ nanotube arrays ample annealed at $500^{\circ} \mathrm{C}$ and (b) the $\mathrm{TiO}_{2}$ nanotube arrays ample annealed at $600^{\circ} \mathrm{C} . \mathrm{A}, \mathrm{R}$, and $\mathrm{T}$ represent anatase, rutile, and titanium, respectively.

Figure $3(\mathrm{~b})$ shows the absorption spectra of the extracts adsorbed on $\mathrm{TiO}_{2}$ electrodes, which were compared with that of $\mathrm{TiO}_{2}$ electrode without any dye sensitization. The bare $\mathrm{TiO}_{2}$ electrode cannot respond to the visible light due to its large band gap of $3.2 \mathrm{eV}$ [24]. However, a broad absorption peak in visible-light region extending from 380 to $680 \mathrm{~nm}$ was observed for the electrodes sensitized with the extracts of tradescantia zebriza, kapok, and pitaya. The natural dye sensitizers are thus found to effectively increase the absorption of the visible light, which dominates the terrestrial solar spectrum.

A close look at Figure 3 could found that the UV-vis absorption peaks of the dyes adsorbed on $\mathrm{TiO}_{2}$ electrodes are broadened and the peak positions are redshift, compared to those in solution. Such phenomenon can be explained as follows. Anthocyanin has a high absorption coefficient in the visible part of the solar spectrum. The binding between anthocyanin molecules and $\mathrm{TiO}_{2}$ semiconductor takes place through the carbonyl and hydroxyl groups. The chemical attachment could affect the energy levels of the highest occupied molecular level and the lowest unoccupied molecular level of the anthocyanidin molecules [25], which eventually affects the band gap and results in a shift of the absorption peak in the absorption spectra. Besides, the redshift of the visible-light absorption peaks could also be due to the complexation with metal ions [15].

\subsection{Photoelectrochemical Performance of DSSCs Sensitized} with Natural Dyes. Figure 4 shows the photocurrent-photovoltage $(J-V)$ characteristics of the DSSCs. The photoelectrochemical parameters evaluated from Figure 4 are summarized in Table 1 . The photoenergy conversion efficiencies $(\eta)$ of the DSSCs sensitized with tradescantia zebriza, kapok, and pitaya are $0.23 \%, 0.3 \%$, and $0.17 \%$, respectively, and the short-circuit photocurrent densities $\left(J_{\mathrm{SC}}\right)$ are $0.63 \mathrm{~mA} / \mathrm{cm}^{2}$, $0.87 \mathrm{~mA} / \mathrm{cm}^{2}$, and $0.50 \mathrm{~mA} / \mathrm{cm}^{2}$, respectively. The values of $\eta$ and $J_{\mathrm{SC}}$ after natural dye sensitization are effectively
TABLE 1: Photoelectrochemical parameters of DSSCs sensitized with three kinds of natural dyes, compared with the solar cell without dye sensitization.

\begin{tabular}{lcccc}
\hline Sensitizer & $J_{\mathrm{SC}}\left(\mathrm{mA} / \mathrm{cm}^{2}\right)$ & $V_{\mathrm{OC}}(\mathrm{V})$ & $\mathrm{FF}$ & $\eta(\%)$ \\
\hline Without dye & 0.023 & 0.3 & 0.494 & 0.006 \\
Tradescantia zebrina & 0.63 & 0.35 & 0.52 & 0.23 \\
Kapok & 0.87 & 0.36 & 0.49 & 0.3 \\
Pitaya & 0.50 & 0.33 & 0.52 & 0.17 \\
\hline
\end{tabular}

TABLE 2: Photoelectrochemical parameters of DSSCs based on $\mathrm{TiO}_{2}$ nanotube arrays annealed at different temperatures.

\begin{tabular}{lcccc}
\hline Annealing temperature & $J_{\mathrm{SC}}\left(\mathrm{mA} / \mathrm{cm}^{2}\right)$ & $V_{\mathrm{OC}}(\mathrm{V})$ & $\mathrm{FF}$ & $\eta(\%)$ \\
\hline $500^{\circ} \mathrm{C}$ & 0.64 & 0.35 & 0.52 & 0.23 \\
$600^{\circ} \mathrm{C}$ & 0.15 & 0.41 & 0.26 & 0.03 \\
\hline
\end{tabular}

enhanced in comparison to that without dye sensitization with the value $\eta$ of $0.006 \%$ and $J_{\text {SC }}$ of $0.023 \mathrm{~mA} / \mathrm{cm}^{2}$, while the open-circuit voltages and the fill factor are similar. This suggests that the chemical adsorption of the natural dye molecules on $\mathrm{TiO}_{2}$ electrodes takes place. The hydroxyl and carboxyl groups on anthocyanin are easy to chelate with $\mathrm{Ti}$ (IV) on $\mathrm{TiO}_{2}$ surface [25]. This helps the excited electron quickly transfer from anthocyanin molecules to the conduction band of $\mathrm{TiO}_{2}$.

It can be seen from Table 1 that the DSSC sensitized with the extracts from kapok exhibits the best value of $\eta$ among the three kinds of dyes. This might be due to the higher intensity and broader range of the visible-light absorption of the extracts from kapok in comparison to the others as shown in Figure 3(b). Furthermore, stronger interaction between $\mathrm{TiO}_{2}$ and the dye molecules of the extracts of kapok also might lead to charge transfer quickly.

The stability of the natural dyes was further studied by continuous irradiation in the sunshine for $2 \mathrm{~h}$ and no significant changes were observed.

3.4. Effect of $\mathrm{TiO}_{2}$ Crystal Structure on the Performance of DSSCs. To further investigate the effect of $\mathrm{TiO}_{2}$ nanotube crystal structure on the natural DSSCs, characteristics of DSSCs at different annealing temperature were measured. As shown in Figure 5 and Table 2, the values of $J_{\mathrm{SC}}$ and $\eta$ for DSSCs based on $\mathrm{TiO}_{2}$ annealed at $500^{\circ} \mathrm{C}$ outperformed those annealed at $600^{\circ} \mathrm{C}$. According to Figure $2, \mathrm{TiO}_{2}$ nanotube arrays annealed at $500^{\circ} \mathrm{C}$ were major anatase phase with minor rutile ones. The electrode possesses the mixed crystal structure. When the temperature increased to $600^{\circ} \mathrm{C}$, the sample has more obvious rutile peaks than the one annealed at $500^{\circ} \mathrm{C}$. The results here suggest that the performance of DSSC based on $\mathrm{TiO}_{2}$ nanotube arrays depends on the proportion of anatase to rutile for $\mathrm{TiO}_{2}$ crystal structure. Besides the crystal structure, the geometric structure of $\mathrm{TiO}_{2}$ nanotube arrays can affect the photoelectrical properties and thus the performance of the DSSCs [11], which requires further experimental investigation. 


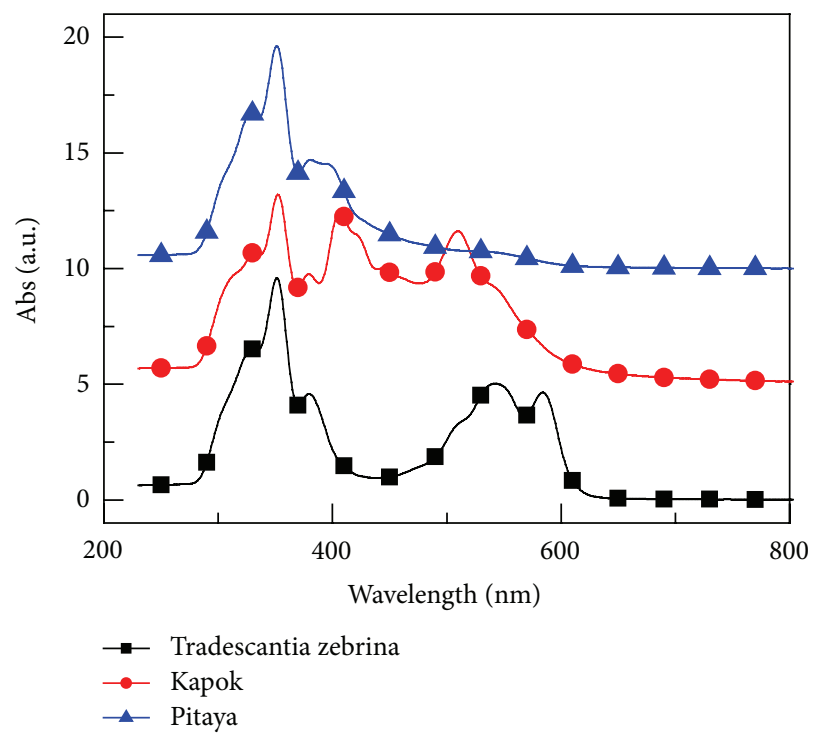

(a)

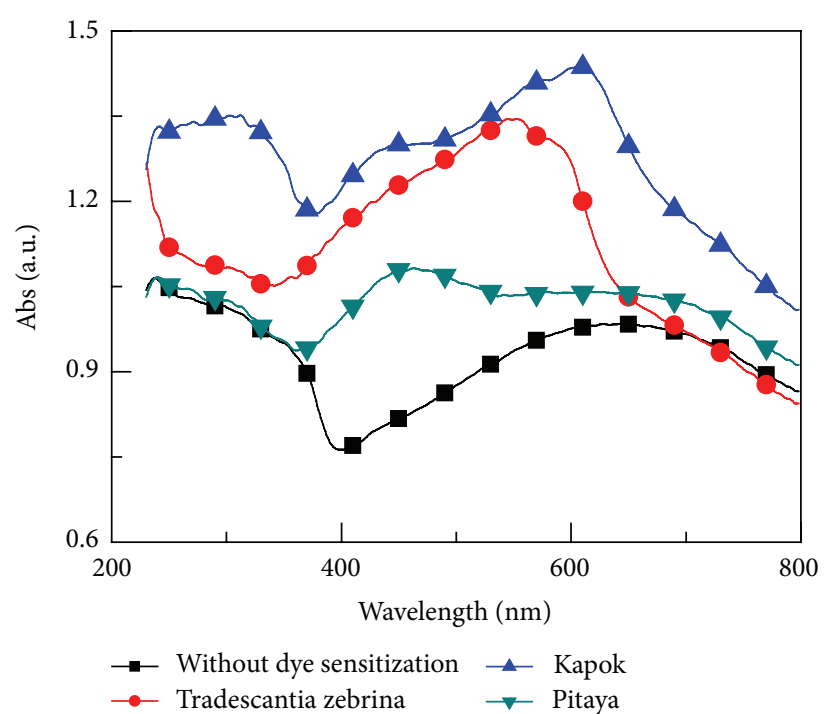

(b)

Figure 3: Comparison of the absorption spectra of the natural extracts: (a) in acid solution; (b) adsorbed on $\mathrm{TiO}_{2}$ electrode.

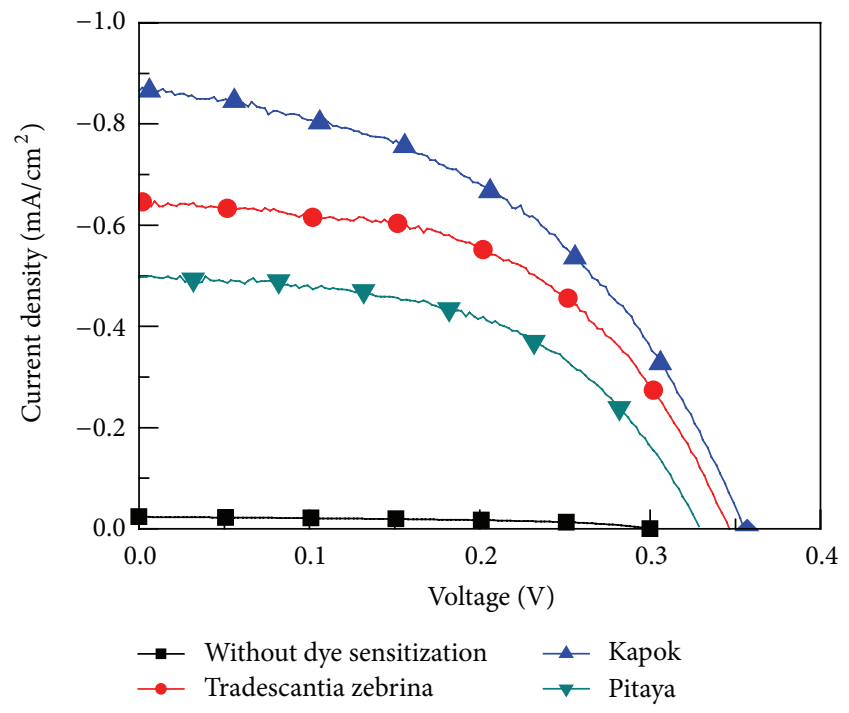

FIGURE 4: $J$ - $V$ characteristics of DSSCs sensitized with three kinds of natural dyes under illumination of $50 \mathrm{~mW} / \mathrm{cm}^{2}$, compared with the solar cell without dye sensitization.

\section{Conclusions}

The feasibility of assembling DSSCs with $\mathrm{TiO}_{2}$ nanotube arrays sensitized with three kinds of natural dyes has been demonstrated. Successful conversion of visible light into electricity was achieved. The efficiencies of the solar cells sensitized with the extracts of Tradescantia zebrine, kapok, and pitaya skin were up to $0.23 \%, 0.3 \%$, and $0.17 \%$, respectively. Crystalline phases of $\mathrm{TiO}_{2}$ significantly affect the photoenergy conversion parameters of DSSCs. Although our best values of DSSCs using kapok pigments are still lower than those obtained for the reference solar cells using the

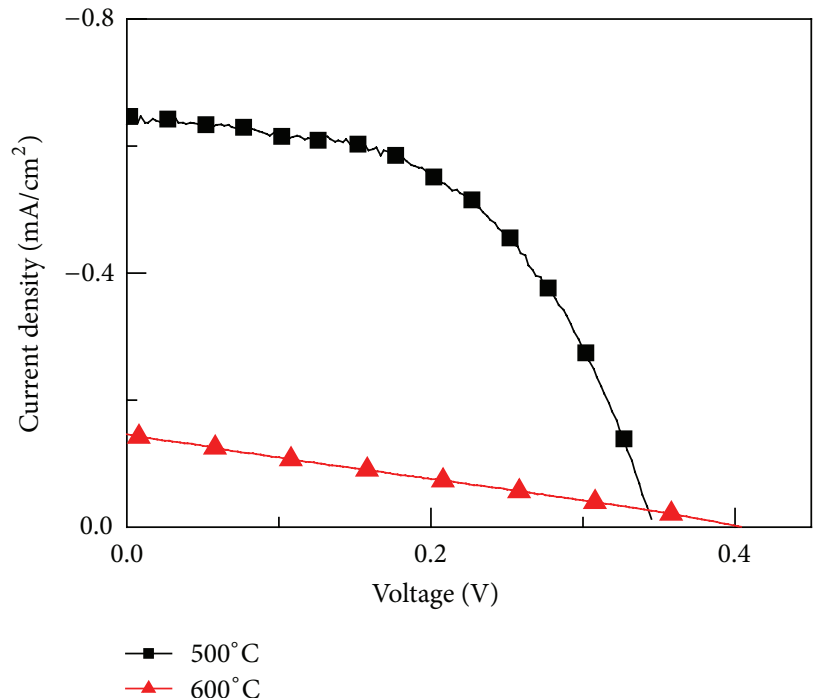

FIGURE 5: $J-V$ characteristics of DSSCs sensitized with extracts of Tradescantia Zebrina based on $\mathrm{TiO}_{2}$ nanotube arrays annealed at different temperatures.

chemical dye N719, the simple extraction procedure, low cost, wide availability, and environmentally friendly nature make natural dyes as the promising sources of sensitizers for DSSCs. Through improving extraction method, refining natural dyes, and optimizing the geometric and crystal structures of $\mathrm{TiO}_{2}$ nanotube arrays, we believe that better results will be achieved.

\section{Acknowledgments}

This work was supported by Program for New Century Excellent Talents in University (NCET-09-0110), National 
Nature Science Foundation of China (51202050), Hainan Natural Science Foundation (511110), and Hainan University Youth Foundation (qnjj1241).

\section{References}

[1] B. O’Regan and M. Grätzel, "A low-cost, high-efficiency solar cell based on dye-sensitized colloidal $\mathrm{TiO}_{2}$ films," Nature, vol. 353, no. 24, pp. 737-740, 1991.

[2] M. Grätzel, "Solar energy conversion by dye-sensitized photovoltaic cells," Inorganic Chemistry, vol. 44, no. 20, pp. 6841-6851, 2005.

[3] J. R. Jennings, A. Ghicov, L. M. Peter, P. Schmuki, and A. B. Walker, "Dye-sensitized solar cells based on oriented $\mathrm{TiO}_{2}$ nanotube arrays: transport, trapping, and transfer of electrons," Journal of the American Chemical Society, vol. 130, no. 40, pp. 13364-13372, 2008.

[4] A. Ghicov, S. P. Albu, R. Hahn et al., " $\mathrm{TiO}_{2}$ nanotubes in dye-sensitized solar cells: critical factors for the conversion efficiency," Chemistry, vol. 4, no. 4, pp. 520-525, 2009.

[5] S. H. Kang, S. H. Choi, M. S. Kang et al., "Nanorod-Based dye-sensitized solar cells with improved charge collection efficiency," Advanced Materials, vol. 20, no. 1, pp. 54-58, 2008.

[6] J. Jiu, S. Isoda, F. Wang, and M. Adachi, "Dye-sensitized solar cells based on a single-crystalline $\mathrm{TiO}_{2}$ nanorod film," The Journal of Physical Chemistry B, vol. 110, no. 5, pp. 2087-2092, 2006.

[7] B. Tan and Y. Wu, "Dye-sensitized solar cells based on anatase $\mathrm{TiO}_{2}$ nanoparticle/nanowire composites," The Journal of Physical Chemistry B, vol. 110, no. 32, pp. 15932-15938, 2006.

[8] P. Roy, D. Kim, I. Paramasivam, and P. Schmuki, "Improved efficiency of $\mathrm{TiO}_{2}$ nanotubes in dye sensitized solar cells by decoration with $\mathrm{TiO}_{2}$ nanoparticles," Electrochemistry Communications, vol. 11, no. 5, pp. 1001-1004, 2009.

[9] G. K. Mor, K. Shankar, M. Paulose, O. K. Varghese, and C. A. Grimes, "Use of highly-ordered $\mathrm{TiO}_{2}$ nanotube arrays in dyesensitized solar cells," Nano Letters, vol. 6, no. 2, pp. 215-218, 2006.

[10] K. Zhu, N. R. Neale, A. Miedaner, and A. J. Frank, "Enhanced charge-collection efficiencies and light scattering in dyesensitized solar cells using oriented $\mathrm{TiO}_{2}$ nanotubes arrays," Nano Letters, vol. 7, no. 1, pp. 69-74, 2007.

[11] D. H. Li, S. W. Lin, S. P. Li et al., "Effects of geometric and crystal structures on the photoelectrical properties of highly-ordered $\mathrm{TiO}_{2}$ nanotube arrays," Journal of Materials Research, vol. 27, no. 7, pp. 1029-1036, 2012.

[12] S. P. Li, S. W. Lin, J. J. Liao et al., "Nitrogen-doped $\mathrm{TiO}_{2}$ nanotube arrays with enhanced photoelectrochemical property," International Journal of Photoenergy, vol. 2012, Article ID 794207, 7 pages, 2012.

[13] A. Yella, H. W. Lee, H. N. Tsao et al., "Porphyrin-sensitized solar cells with cobalt (II/III)-based redox electrolyte exceed 12 percent efficiency," Science, vol. 334, no. 6056, pp. 629-634, 2011.

[14] W. M. Campbell, A. K. Burrell, D. L. Officer, and K. W. Jolley, "Porphyrins as light harvesters in the dye-sensitised $\mathrm{TiO}_{2}$ solar cell," Coordination Chemistry Reviews, vol. 248, no. 13-14, pp. 1363-1379, 2004.

[15] N. J. Cherepy, G. P. Smestad, M. Grätzel, and J. Z. Zhang, "Ultrafast electron injection: implications for a photoelectrochemical cell utilizing an anthocyanin dye-sensitized $\mathrm{TiO}_{2}$ nanocrystalline electrode," The Journal of Physical Chemistry B, vol. 101, no. 45, pp. 9342-9351, 1997.

[16] K. Wongcharee, V. Meeyoo, and S. Chavadej, "Dye-sensitized solar cell using natural dyes extracted from rosella and blue pea flowers," Solar Energy Materials and Solar Cells, vol. 91, no. 7, pp. 566-571, 2007.

[17] G. Calogero and G. D. Marco, "Red Sicilian orange and purple eggplant fruits as natural sensitizers for dye-sensitized solar cells," Solar Energy Materials and Solar Cells, vol. 92, no. 11, pp. 1341-1346, 2008.

[18] E. Yamazaki, M. Murayama, N. Nishikawa, N. Hashimoto, M. Shoyama, and O. Kurita, "Utilization of natural carotenoids as photosensitizers for dye-sensitized solar cells," Solar Energy, vol. 81, no. 4, pp. 512-516, 2007.

[19] Q. Dai and J. Rabani, "Photosensitization of nanocrystalline $\mathrm{TiO}_{2}$ films by pomegranate pigments with unusually high efficiency in aqueous medium," Chemical Communications, no. 20, pp. 2142-2143, 2001.

[20] H. Omidvar, S. Goodarzi, A. Seif, and A. R. Azadmehr, "Influence of anodization parameters on the morphology of $\mathrm{TiO}_{2}$ nanotube arrays," Superlattices and Microstructures, vol. 50, no. 1, pp. 26-39, 2011.

[21] A. Ghicov and P. Schmuki, "Self-ordering electrochemistry: a review on growth and functionality of $\mathrm{TiO}_{2}$ nanotubes and other self-aligned MOx structures," Chemical Communications, no. 20, pp. 2791-2808, 2009.

[22] Q. Dai and J. Rabani, "Photosensitization of nanocrystalline $\mathrm{TiO}_{2}$ films by anthocyanin dyes," Journal of Photochemistry and Photobiology A: Chemistry, vol. 148, no. 1-3, pp. 17-24, 2002.

[23] F. G. Gao, A. J. Bard, and L. D. Kispert, "Photocurrent generated on a carotenoid-sensitized $\mathrm{TiO}_{2}$ nanocrystalline mesoporous electrode," Journal of Photochemistry and Photobiology A: Chemistry, vol. 130, no. 1, pp. 49-56, 2000.

[24] M. Grätzel, "Perspectives for dye-sensitized nanocrystalline solar cells," Progress in Photovoltaics: Research and Applications, vol. 8, no. 1, pp. 171-185, 2000.

[25] S. Meng, J. Ren, and E. Kaxiras, "Natural dyes adsorbed on $\mathrm{TiO}_{2}$ nanowire for photovoltaic applications: enhanced light absorption and ultrafast electron injection," Nano Letters, vol. 8, no. 10 , pp. 3266-3272, 2008. 

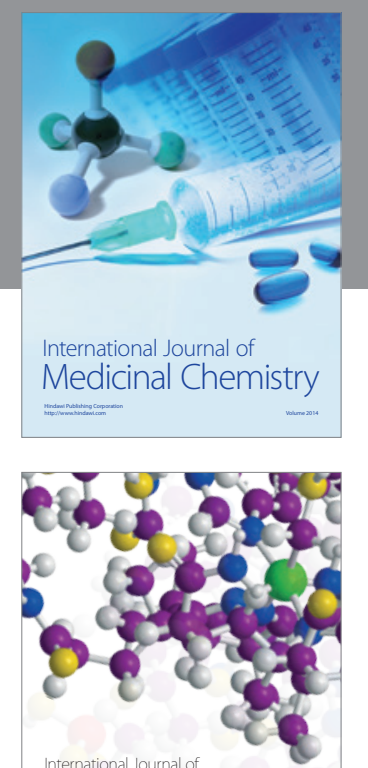

\section{Carbohydrate} Chemistry

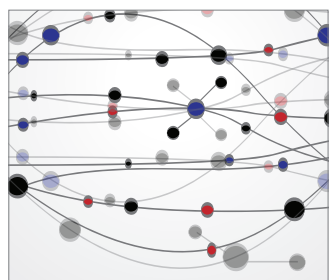

The Scientific World Journal
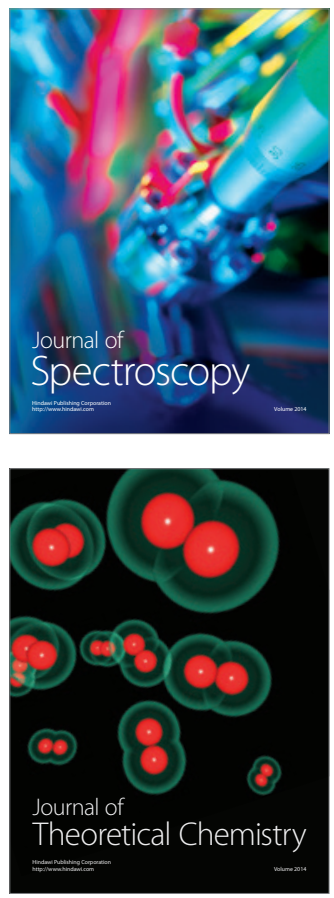
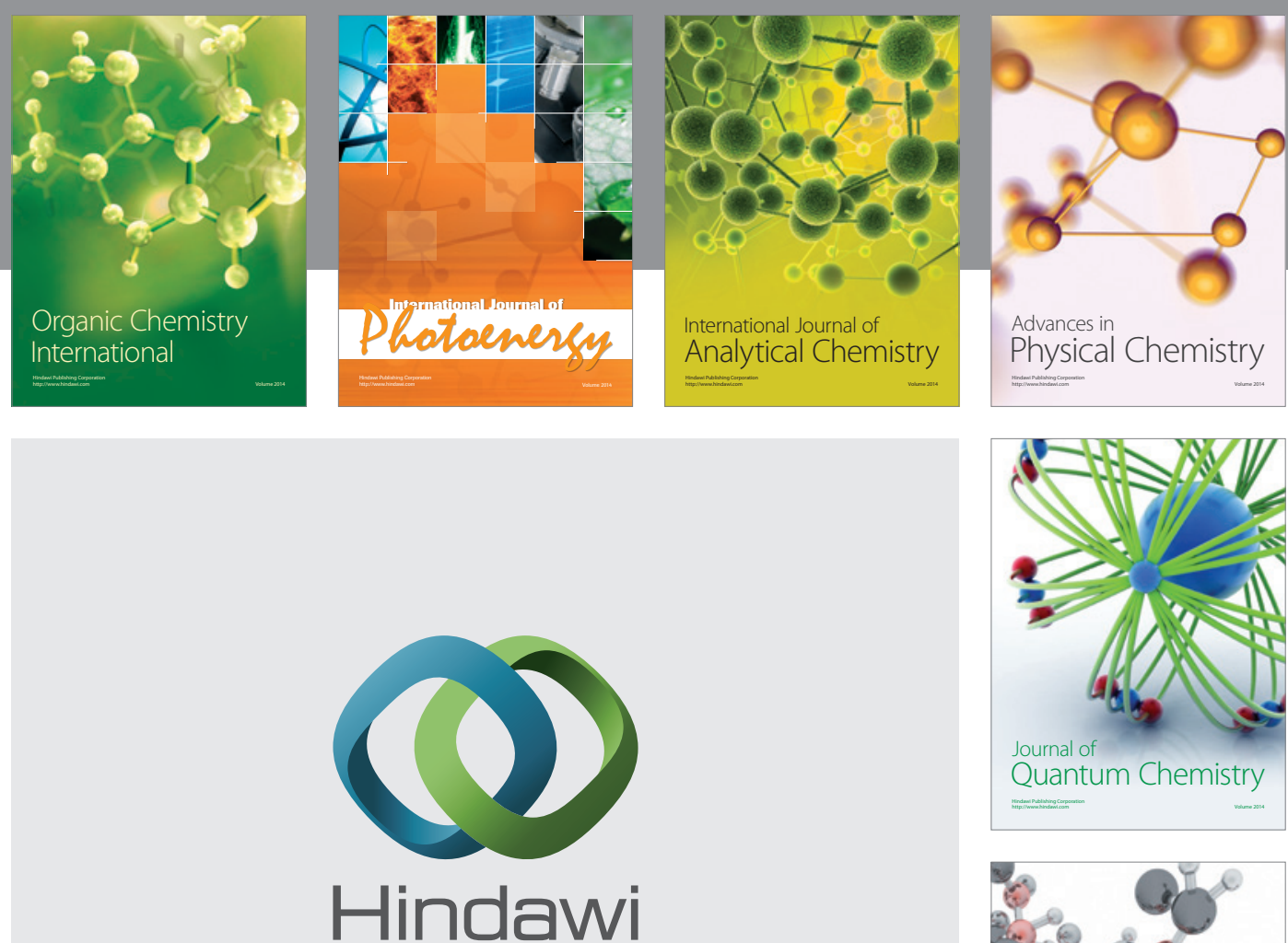

Submit your manuscripts at

http://www.hindawi.com

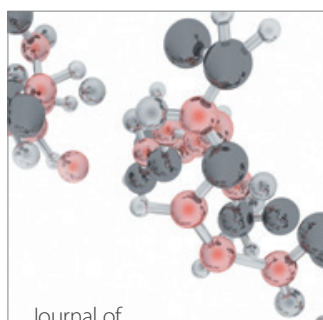

Analytical Methods

in Chemistry

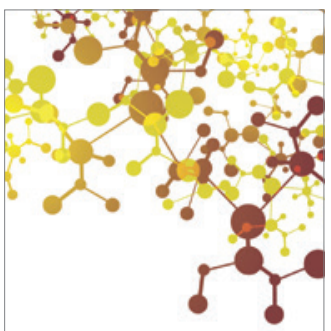

Journal of

Applied Chemistry

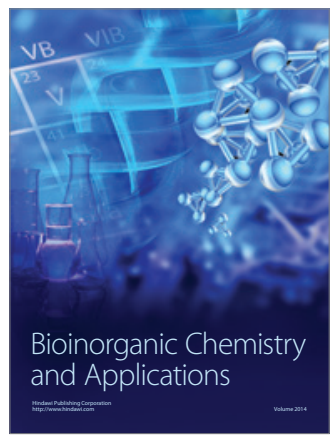

Inorganic Chemistry
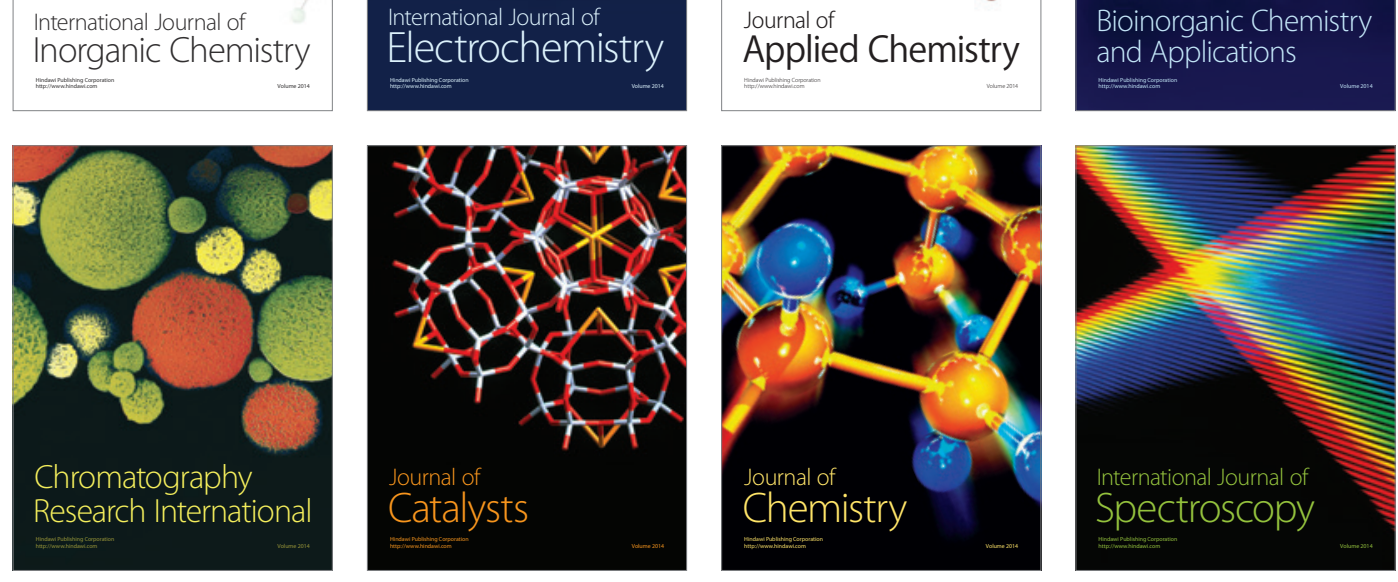